\title{
SEBUAH REFLEKSI DAN INTROSPEKSI BUDAYA DALAM JOURNEY INTERNATIONAL OPENAIR EXPRESSIONS 2008 HIKI
}

\author{
M. Dwi Marianto ${ }^{1}$
}

\begin{abstract}
Technically speaking, the journey and experience during the IOE 2008 participation in Japan can be seen as a subject of aesthetic-cultural reflection. In this case, there is no boundary line between the art works that were exhibited in the event with the phenomena of the city which was very greatly attracted the artist. The way how to see and to perceive the phenomena of the nature and culture presented, such as the city center atmosphere, the open space, the spontaneous behaveor of the public, and the city sreets,directly and indirectly, were influenced by the content of the references.
\end{abstract}

Keywords: journey, culture, and the art of life.

Sebuah refleksi budaya perjalanan yang telah dilakukan ke Jepang, 8 September s/d 17 September 2008, dalam rangka mengikuti International Openair Expression 2008 Hiki, di Saitama, Jepang yang diselenggarakan di kampus Tokyo Denki University. Dalam kerangka perhelatan itu panitia mengundang penulis untuk memberi suatu ceramah mengenai seni kontemporer pada hari acara pembukaan IOE 2008, di Tokyo Denki University, tepatnya di Departemen Informatika dan Seni, yang dihadiri oleh para peserta IOE 2008, sejumlah seniman, mahasiswa, dosen dan peminat seni. Kesempatan diberikan berceramah tentang seni kontemporer dalam arti yang luas; untuk itu ceramahnya dengan power-

${ }^{1}$ M. Dwi Marianto adalah Dosen Pascasarjana Institut Seni Indonesia Yogyakarta. 
point berjudul "Levitation via Art”, menyoroti beberapa praktek dan fenomena seni yang dianggap mampu membangkitkan daya hidup dari audience yang kebetulan bersinggungan dengan karya seni dan seni yang bersangkutan. Selain membicarakan beberapa karya yang secara purposif terpilih sebagai sampel, dan dikemukakan beberapa hasil amatan atas fenomena budaya di seputar pameran, kampus, tempat penginapan, suasana kota di seputar hotel (tempat menginap) dekat Oeno Stationstasiun utama di kota yang bernilai sejarah pada periode setelah PD II.

Artikel ini diawali dengan satu ucapan bijak dari seorang kawan yang telah mengalami satori (sebuah kata Jepang yang artinya pencerahan), yaitu dari pepatah kuno China yang bunyinya: "Kalau kamu menemui sesuatu yang berat dan tidak terhindarkan, janganlah kamu melawannya, sebab dirimu akan hancur, atau paling tidak terluka. Untuk mengatasinya terimalah sesuatu itu dengan ikhlas dan baik”. Pengalaman dari membuka diri atas alam-budaya yang tergelar begitu saja, dan yang didapatkan dari mengamati beberapa fenomenon budaya di ruang publik, merupakan sesuatu yang mencerahkan. Sebab kenyataan sosial-budayanya begitu berbeda dari apa yang secara nyata menggejala di Indonesia, khususnya di Yogyakarta. Sebagai ilustrasi pembuka, di Ueno yang merupakan bagian dari kota metropolitan Tokyo, terdapat taman publik yang benar-benar alami, penuh pepohonan besar, pertamanan, dan ruang-ruang terbuka yang asri dan nyaman, tempat burung-burung gagak bebas berkeliaran. Masyarakat memanfaatkan taman itu untuk berbagai aktivitas, dari jogging, membaca, rekreasi, menikmati bunga sakura secara kolektif di musim semi, sampai sekedar duduk-duduk mencari oksigen murni dari berbagai flora yang ada disana. Di Yogyakarta, dan di banyak kota lainnya di Nusantara, yang masyarakatnya berpretensi berbudaya dan religius, realita objektif yang terjadi justru sebaliknya, tak ada ruang-ruang publik yang asri dan gratis bagi masyarakat umum; hampir semua serba harus dibayar; tak ada tempat-tempat alami yang aman bagi binatang-binatang liar, lantaran ditangkapi atau ditembaki. Pusat kota di Jepang biasanya berupa daerah yang dibiarkan lapang alami, ditandai dengan taman luas tertata ala Jepang, keselarasan dengan alam jadi landasan estetis mereka. Keadaan macam ini berbeda dari pusat kota yang lazimnya ditemui di negeri ini yang lazimnya sarat toko-toko, bangunan-bangunan perkantoran yang biasanya minim ruang-ruang kosong serta miskin pepohonan besar. Estetika taman-taman kota sama menariknya dengan karya-karya seni 
yang tergelar di perhelatan seni. Tampilan sebuah taman kota adalah cerminan budaya masyarakatnya.

Suasana keseharian di jalan raya dan ruang publik yang menyangkut transportasi umum secara signifikan tertuang dalam performa yang berjalan dengan keteraturan, ditambah dengan regulasi yang terkelola baik. Orang sudah berfikir dalam hitungan menit dari stasiun yang satu ke stasiun lainnya. Perjalanan dari Stasiun Ueno ke Narita Airport Station dapat dicapai dengan dua macam kereta. Yang satu memakan waktu lebih kurang 85 menit, dan kereta lain hanya 60 menit. Selisih waktunya hanya 25 menit, namun perbandingan antara kedua tiketnya adalah 1: 2, yaitu 1000 Yen: 2000 Yen. (1 Yen kira-kira 83 Rupiah waktu itu) Waktu telah terkelola baik dalam sistem transportasi umum di Jepang, hingga pertemuan-pertemuan bisnis sering dilakukan di dalam atau di seputar kompleks stasiun. Di Indonesia waktu masih dilihat sebagai sesuatu yang mengalir begitu saja, berbeda dibanding waktu yang dilihat oleh masyarakat disana, dan sampai sekarang di Indonesia masih terbatas dua lembaga saja yang menghargai waktu secara tepat, yaitu: lembaga ketentaraan dan lembaga keagamaan. Diluar kedua lembaga ini waktu masih terhambur percuma, seperti banyak air sungai dan selokan yang belum dirawat, dikelola, dan dimanfaatkan secara baik, jam karet masih menjadi realita keseharian umum di banyak tempat dan perhelatan.

\section{HIKMAH JARINGAN KERJA}

Pekerjaan dapat dilakukan lebih cepat dan tidak berbelit-belit via jaringan kerja. Pada awalnya seorang bekas mahasiswa Pascasarjana Institut Seni Indonesia Yogyakarta - Seiko Kaijura - pada akhir 2007 melayangkan tawaran untuk mengikuti International Openair Expressions 2008 di Saitama, Jepang. Ini adalah suatu event seni yang telah berjalan selama tiga tahun. Bukan hanya berpartisipasi sebagai seniman peserta, namun diundang pula untuk memberi satu ceramah mengenai seni kontemporer di Tokyo Denki University. Akhirnya terjadi kesepakatan antara sang organiser Yuguen Onodera (seorang pematung yang sering mengorganisir art events) dan penulis. Pada 8 September 2008 telah mendarat di Narita International Airport dengan Garuda Indonesia Airways 


\section{Sebuah Refleksi dan Inrospeksi ... (M. Dwi Marianto)}

Sesampainya di Narita Airport telah menunggu seorang teman, bernama Yu Endo, mengantar ke Saitama naik kereta Keisei Line di kawasan bandara ke Nippori yang berada di kawasan kota Metropolitan Tokyo. Memakan waktu 60 menit. Ongkosnya 1000 Yen, atau sekitar Rp. 83.000,-. Keretanya bersih, sign system di lingkungan stasiun dan yang ada dalam kereta api dibuat bi-lingual (English dan Jepang). Para penumpang dalam kereta pada umumnya tidak berbicara satu sama lain, masing-masing asyik dengan aktivitas pribadi, seperti: membaca buku atau manga (komik), mendengarkan musik via i-pod, ber-sms-an, atau tertunduk tidur di kereta. Jadwal perjalanan kereta sudah berjalan teratur dan terukur. Lama perjalanan dari stasiun yang satu ke stasiun lain telah dituliskan secara grafis, dalam hitungan menit, misalnya: 2 atau tiga menit, atau lebih; semuanya tepat waktu serta tertib tempat berhenti. Dari Nippori kemudian naik kereta lain, ke Ikebukuro, 160 Yen tiketnya; dan dari Ikebukuro naik kereta ke Takasaka. Cukup jauh, maka proporsional-lah kalau tiketnya 630 Yen.

Dari Stasiun Takasaka naik bus Tokyo Denki University, yang tersedia bagi warga dan tamu TDU yang bepergian dari atau ke TDU secara gratis. Sebenarnya ada bus langsung dari Saitama ke Narita, namun tiketnya hampir dua kali lipat, sebab routenya langsung, tidak berhenti. Di setiap stasiun selalu ada pelataran parkir yang cukup luas untuk menaruh sepeda. Masyarakat Jepang telah memanfaatkan jasa perkeretaapian secara baik. Dari tempat tinggal mereka berjalan kaki atau naik sepeda, lalu naik kereta ke tempat kerja atau ke tempat tujuan. Area parkiran sepeda selalu penuh. Demikian pula di kampus, cukup banyak warganya yang naik sepeda. Kenyataan ini sungguh kontras dengan apa yang pada umumnya terjadi di Indonesia kini; tempat parkiran biasanya penuh dengan sepeda motor yang hampir semuanya produk Jepang.

Panitia di TDU menyediakan satu ruang, dilengkapi dengan satu unit komputer yang terhubung dengan internet untuk para seniman peserta IOE 2008, untuk bekerja, menyimpan barang, atau untuk sekedar beristirahat. Ada beberapa vending machines yang menjual berbagai produk, dari air murni pegunungan, berbagai macam juice, dan ruparupa teh, kopi susu, sampai berbagai produk bir. Para peserta keluarmasuk ruang sesuai keperluan. Aman. Panitia memang menyediakan waktu beberapa hari bagi para peserta untuk bisa mengerjakan karya yang kebanyakan di-install outdoor. Beberapa karya dipasang dalam 
ruang, ada yang tergantung, dan ada yang didisplay pada panel. Sisanya dibuat di dalam hutan di seputar TDU dan di Sennendani Park. Hutan di sekitar kampus sangat menarik perhatian. Berbagai macam pohon hidup leluasa dan terpelihara; empang-empang dan aliran-aliran air terjaga kejernihan dan kealamiahannya. Kampus TDU sangat bersih. Di manamana ada 3 kontainer penampung sampah untuk: botol-botol plastik; benda-benda yang mudah terbakar; dan sampah organik. Sekitar kampus banyak selokan yang airnya mengalir, jernih, bebas dari limbah plastik. Kesadaran akan pentingnya menjaga lingkungan alami telah menjadi praktek keseharian masyarakatnya. Di ruang terbuka, orang bisa berjalan, jogging, dan beraktivitas olah-raga. Ada pula fountain di ruang-ruang publik, orang bisa minum air yang segar dan bersih.

Ada fenomena budaya dalam atmosfir kerja di antara para peserta, yaitu bahwa mereka sudah terbiasa bekerja secara individual; secara relatif masyarakat di Jepang tidak suka berbicara panjang-lebar, melainkan lebih nampak larut dalam pekerjaannya sendiri. Ini semakin dikuatkan nantinya dalam acara menjelang Pembukaan IOE 2008 pada tanggal 13 September 2008, khususnya dalam acara art tour. Organiser membawa para peserta pameran dan pemerhati seni berjalan dalam satu route, meninjau satu per satu karya yang digelar. Peserta yang karyanya didatangi diminta untuk memberi pernyataan seninya selama kuranglebih satu menit. Hasilnya terbaca bahwa masyarakat telah terbiasa dengan tata-laku menyampaikan sesuatu tentang karyanya secara singkat. Tidak mengobral estetika melalui kata-kata. Demikian pula dalam Acara Pembukaan, tidak ada pemaparan tentang karya dan pameran secara bertele-tele. Masyarakat Jepang lebih senang berbicara melalui karya dan kerja, tidak suka dengan orasi yang panjang-panjang. Energi untuk itu nampaknya tersalur melalui penulisan buku atau melalui manga (komik) yang meliput dinamika sosial-budaya dari segmen-segmen masyarakat pembaca. Kecenderungan ini sejalan sikap religiusitas dan spritualitas, yang lebih cenderung untuk menyatakan dengan karya dan aksi-aksi dalam berbagai rentetan tata-laku yang bersifat non-verbal.

\section{KARYA-KARYA TERGELAR}

Para peserta pameran sangat beragam, dari pemula sampai senior. Kualitas dan kedalaman makna dan komitmen artistiknya pun bervariasi. Ada yang minimalis, ada yang dibangun dan digelar dengan tingkat 
kesukaran yang besar. Ada yang biasa-biasa, namun ada pula yang menampilkan karya nan impresif dalam tataran ide dan teknik eksekusinya. Maka dalam tulisan ini hanya akan disoroti sebagian dari karya-karya terpilih, sebagai sampel, diantaranya: karya yang dibuat dengan tingkat kesukaran teknis yang tinggi dan dengan eksekusi nan rumit; karya-karya dengan keunikan media dan kekhasan penyajian; dan karya-karya dengan pesan yang provokatif menyentak pemirsa.

Presentasi yang paling menarik dalam IOE 2008 adalah suguhan keramik Yuzo Taniguchi berjudul Time-Dreaming Sphere, terpasang secara elegant di halaman kampus TDU pada rerumputan yang hijau terpelihara. Ukuran karya itu terbilang besar. Terdiri dari dua bejana berglasir celadon. Tubuh keramik ini bekerja secara fungsional luardalam, menampilkan dua sifat berbeda dari satu bejana, bagian luar menyiratkan ketenangan dan kedamaian, namun bagian dalamnya menyiratkan suatu evolusi pertumbuhan yang menakutkan tentang kota yang perkembangannya semakin jauh dari kehidupan yang telah beranjak jauh dari kealamiahan dan kesederhanaan.

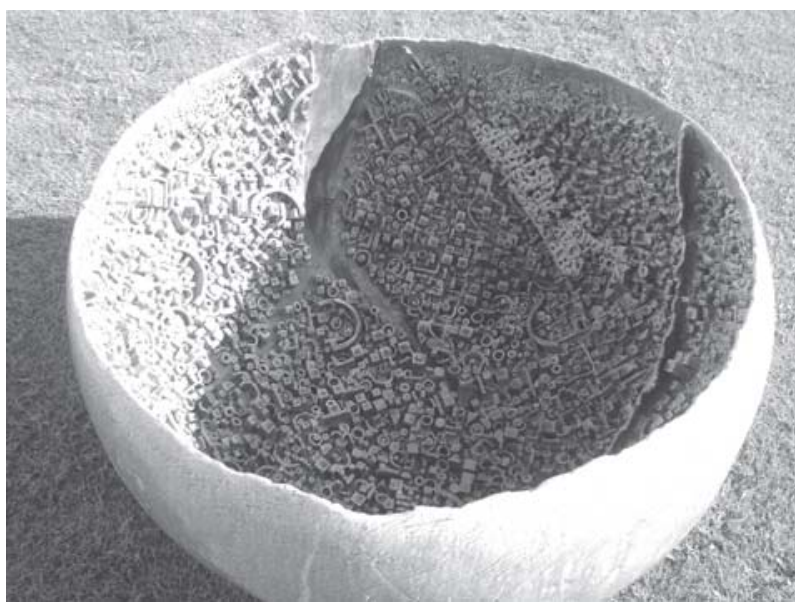

Gambar 1. Yusa Taniguchi, Time-Dreaming Sphere (karya keramik)

Kira-kira 60 meter dari karya keramik tersebut di atas, pada halaman berumput yang sama, digelar satu rangkaian instalasi yang terdiri dari 9 unit, masing-masing berbeda satu dari lainnya. Setiap unit merepresentasi suatu gambaran suatu sell dengan keunikan struktural tersendiri. Ukuran setiap unit kira-kira berdiameter 5 meter. Ada yang 
disusun dari potongan-potongan bambu; ada yang dirangkai dari penggalan-penggalan benda yang dulu merupakan komponen mesin dan badan kendaraan bermotor; ada yang disusun dari batu-batu yang dideretkan atau dijajarkan: ada satu unit yang berupa instalasi bambu yang dianyam seperti sebuah kandang atau rumah yang di dalamnya berserakan botol-botol plastik bekas minuman. Karya ini oleh si pembuatnya, Hanjyo Katsuki, diharapkan dilihat dari atas dengan cara pandang mata burung dan diandaikan sebagai 9 sell yang masing-masing punya bentuk dan struktur sendiri.

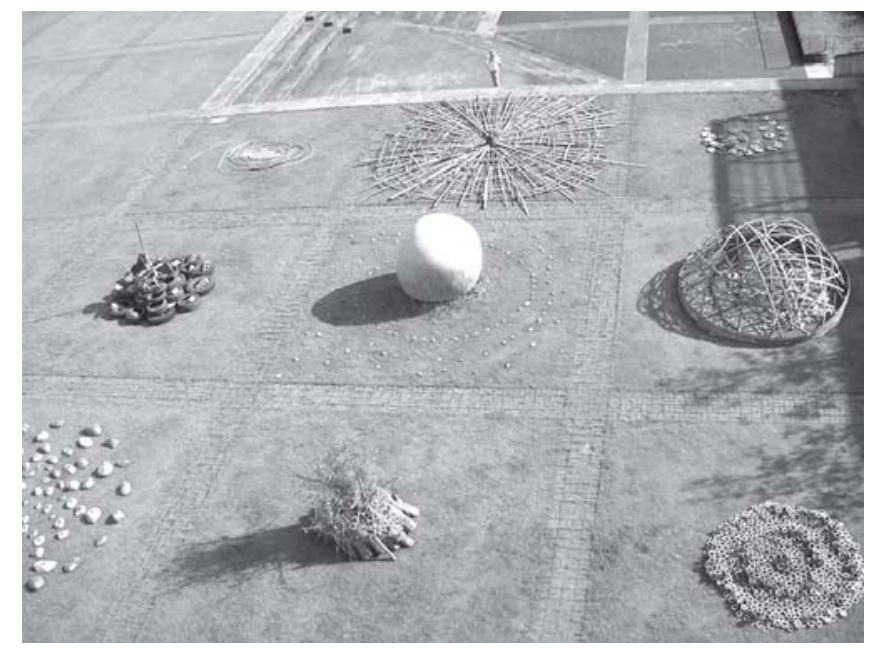

Gambar 2. Hanjyo Katsuki, Bamboo Spiral (karya instalasi)

Rupanya bambu merupakan material yang sering dipergunakan sebagai media instalasi oleh para seniman di Jepang. Sekelompok mahasiswa arsitektur dengan bimbingan seorang dosen membuat satu instalasi bambu berjudul Bamboo Spiral. Karya kolektif itu di-install di bagian depan kampus berseberangan dari building sign TDU. Konstruksinya terukur dan ritmis seperti sebuah organ dengan konstruksi yang rumit. Seorang seniman lain, Katsuaki Kimura, menampilkan satu instalasi bambu seperti abstraksi sebuah bangunan rumah, dipasang di sebuah taman yang berada di luar kampus. Seiko Kajiura, seniman Jepang yang pernah belajar di Program Pascasarjana Institut Seni Indonesia Yogyakarta, membuat kerangka rumah sederhana dari bambu, 


\section{Sebuah Refleksi dan Inrospeksi ... (M. Dwi Marianto)}

yang ditempeli dengan elemen berbentuk burung, dipasang pada sebuah pohon dalam hutan di pinggiran kampus.

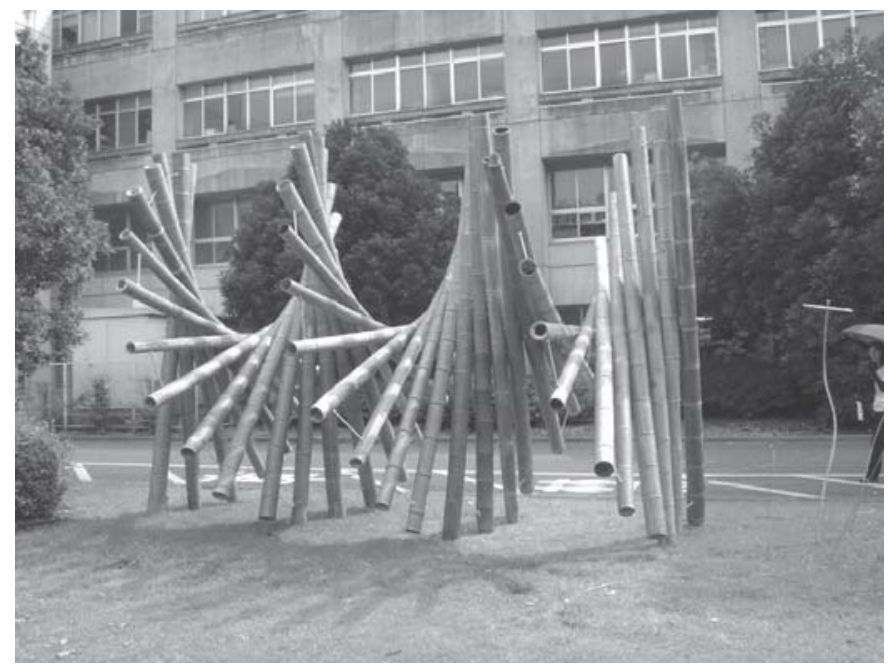

Gambar 3. Bamboo Spiral, (karya instalasi mahasiswa arsitektur TDU)

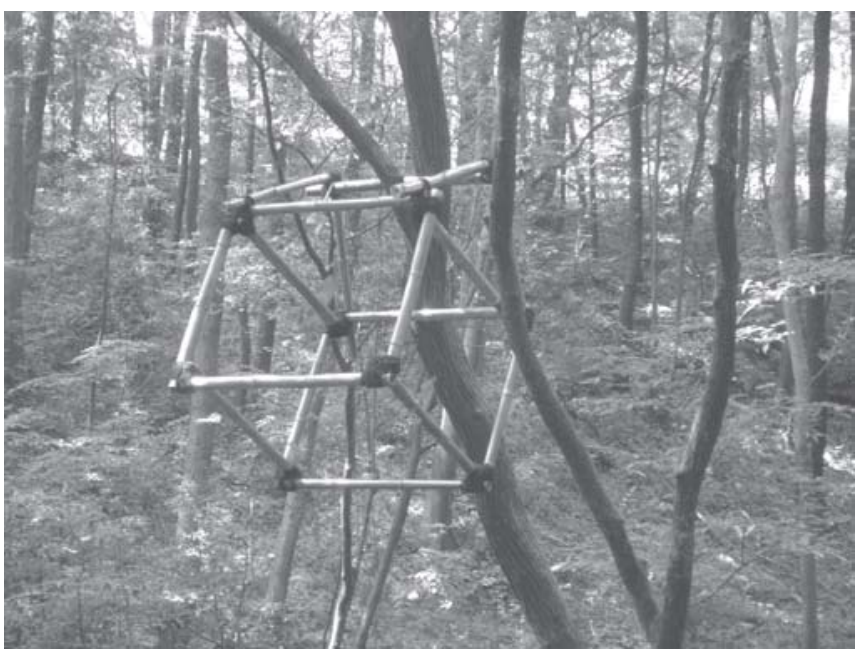

Gambar 4. Seiko Kajiura (karya instalasi) 
Karya dengan cakupan fisik yang luas dengan tingkat kesukaran dalam pengerjaannya karena diinstall pada sebuah jembatan bertiang tunggal berukuran raksasa, adalah karya Mariko Honda berjudul Redline Connection. Honda mengaitkan struktur beton jembatan dan pinggiran empang di bawahnya dengan jalinan tali merah. Dalam kesempatan ini ia memanfaatkan dimensi jembatan yang menjadi landmark daerah itu yang bersebelahan dengan Sennendani Park dan lapangan baseball. Talitali berseliweran seputar struktur jembatan itu nampak spektakuler. Talitali berwarna merah yang berjalan dari atas ke bawah, ke kiri-kanan, memberdayakan karya ini menjadi pemecah keheningan dan keharmonisan lingkungan disana yang secara keseluruhan bersih, tertata, dan terawat. Sekaligus karya ini membongkar keadaan, orang tidak lagi merasakan benda-benda, bangunan, atau suasana sekitar, karena saking sudah terbiasanya. Jembatan itu yang 'mengangkangi' lembah untuk menyangga sebuah jalan raya, boleh jadi telah tak lagi terasakan sensasinya bagi penduduk disana. Instalasi Honda membuat orang jadi sadar kembali akan eksistensi jembatan itu.

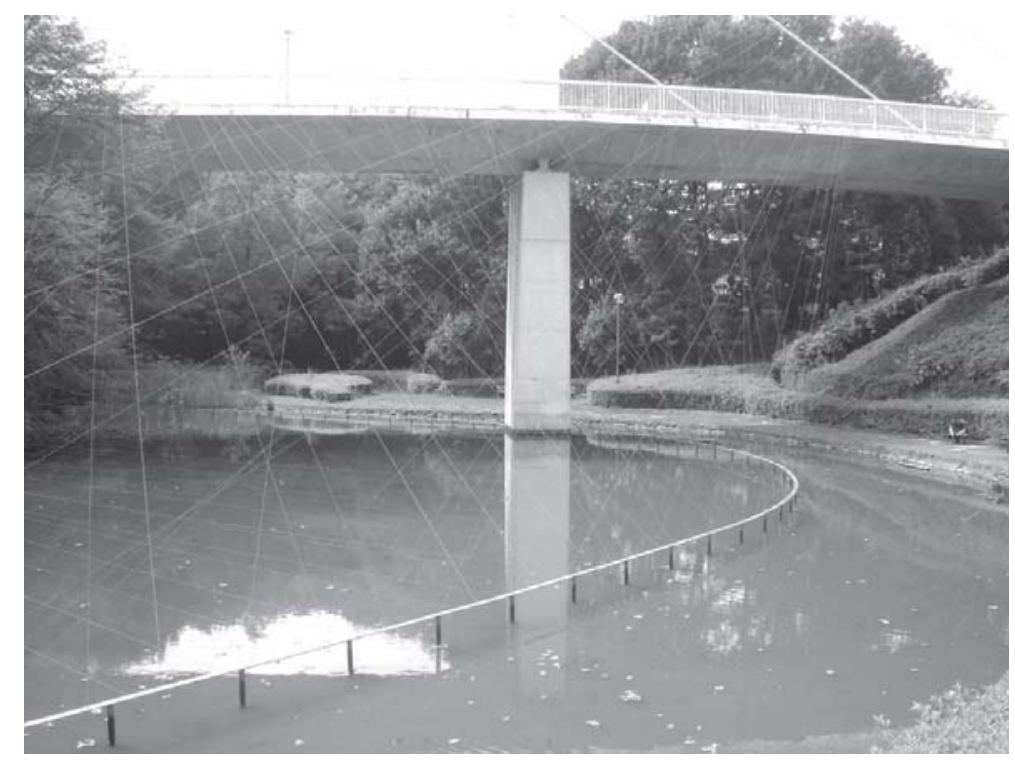

Gambar 4. Moriko Honda, Redline Conection (karya instalasi) 
Yuko Yoshida, seniman yang sering membuat karya instalasi atau melukis dengan tali, menghadirkan sebuah instalasi di halaman universitas. Ia pancangkan tiga bilah bambu utuh pada satu titik yang sama. Bambu itu diambil dari daerah sekitar. Di Saitama terdapat banyak hutan bambu yang terjaga, dari sana lah masyarakat mengambil bambu untuk keperluan sehari-hari. Pada masing-masing pancangan bambu itu dipasangi jaring yang dibentangkan dengan tarikan tali keluar. Sementara itu pada jaring-jaring terbentang itu ia jahitkan potongan-potongan plastik dan kelenting yang akan bergerak-gerak bila tertiup angin kencang, dan sekaligus menimbulkan bunyi dengan tingkat kekerasan yang naik-turun.

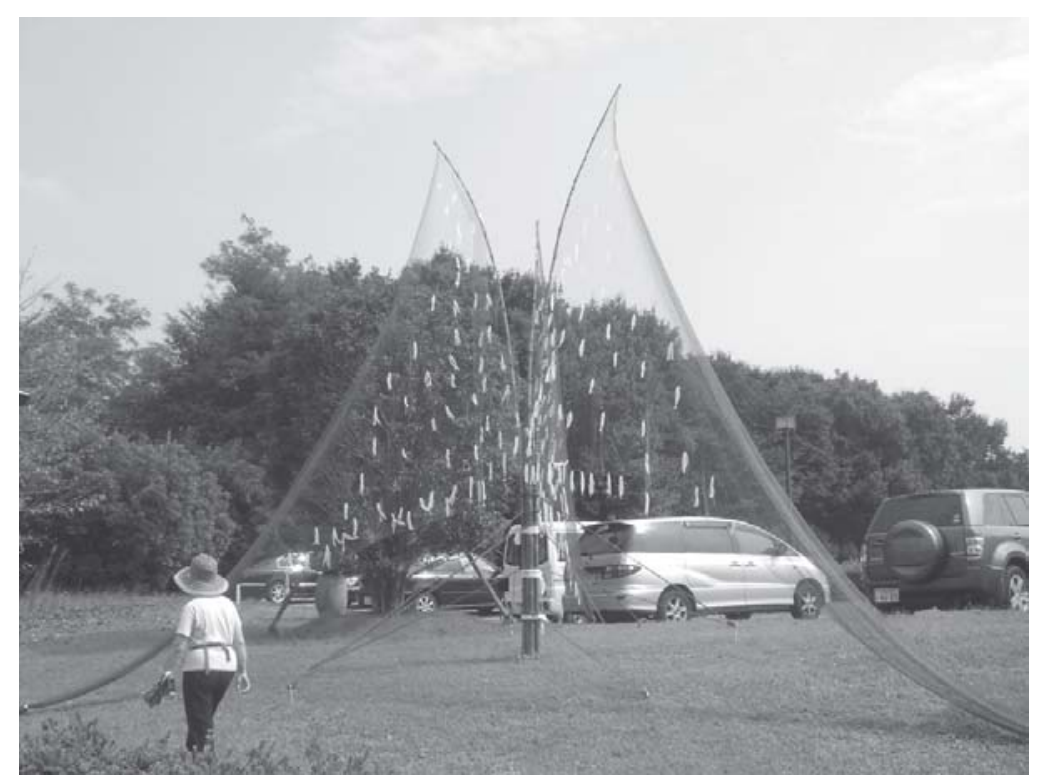

Gambar 5. Yuko Yoshida (karya instalasi)

Ada karya yang idenya diambil dari suasana ketika para petugas jalan raya sedang menggarap sesuatu di jalan raya atau di tempat-tempat yang dilewati publik. Di Jepang ada kebiasaan yang layak ditiru, yaitu budaya mempertimbangkan dan menjaga keselamatan pemakai jalan. Apabila mereka sedang mengerjakan sesuatu di jalan raya atau ruang publik, selalu ada beberapa orang petugas berbaju kerja aman yang 
dikerahkan untuk memberi aba-aba kepada pemakai jalan untuk berhatihati dan mengambil jalur yang telah dipersiapkan. Dengan pakaian kerja yang dilengkapi reflektor, berhelem, orang-orang yang bertugas membawa lampu tanda yang menyala merah. Bentuknya seperti tongkat yang dipegang dan digerak-gerakkan sesuai tanda apa yang mau disampaikan kepada khalayak. Tanda-tanda berupa lampu yang berputarputar, berkedip-kedip, dan dapat mengeluarkan suara tanda bahaya bila dihidupkan, yang berfungsi menyadarkan orang akan apa yang terjadi di tempat itu merupakan perlengkapan standar. Rupanya tanda-tanda dan suasana seperti inilah yang diambil oleh Tatsuya Fujii untuk membuat satu instalasi di pematang pinggiran sebuah empang dalam hutan kampus. Instalasi yang diberi judul Under Construction itu dirangkai dengan tanda-tanda yang dipasang di jalan raya bila ada sesuatu yang bersifat kritis. Fujii memakai sebuah lampu tanda, karakter kanji, tanda palang menyatakan 'dilarang lewat', dan tanda anak panah yang mengarahkan pejalan kaki.

Saya sendiri menampilkan sebuah karya instalasi yang dibuat di suatu pelataran rumput miring dimana building sign bertuliskan TDU ditempatkan. Saya sengaja memilih tempat itu, karena saya menginginkan karya saya terlihat jelas, bukan oleh warga TDU saja tetapi juga oleh orang-orang yang berkendaraan atau yang sekedar lalulalang di jalan raya depan kampus TDU. Instalasi yang saya kerjakan ini berjudul Track of Life Force, disusun dari batu-batu alami dalam bentuk geometrik nautilus dengan perbandingan metrik yang sama. Di bagian tengah ujud nautilus saya pasang tiga pacul yang saya bawa dari Indonesia, yaitu pacul bekas yang dulu bagi pemiliknya merupakan alat utama. Tiga pacul itu saya tancapkan begitu saja pada tanah berrumput. Ujud geometrik nautilus yang juga dapat ditemui pada ujud sulur adalah satu ujud yang bersifat universal, terdapat dalam ujud dasariah makhluk hidup. Simbol universal ini saya kombinasikan dengan pacul yang mewakili teknologi pengolahan alam. Gagang pacul punya ragam ergonomis dan varian bentuk yang beragam, setiap daerah punya keunikan sendiri. Saya membawa tiga pacul dari tiga daerah berbeda: Jawa Barat, Jawa Tengah dan Yogyakarta. Pacul dan ujud geometris nautilus adalah dua hal berbeda yang saya posisikan berdekatan saling mengisi untuk membangkitkan Daya Hidup - levitational force - yang merupakan salah satu fungsi mengapa manusia selalu membuat karya seni. 


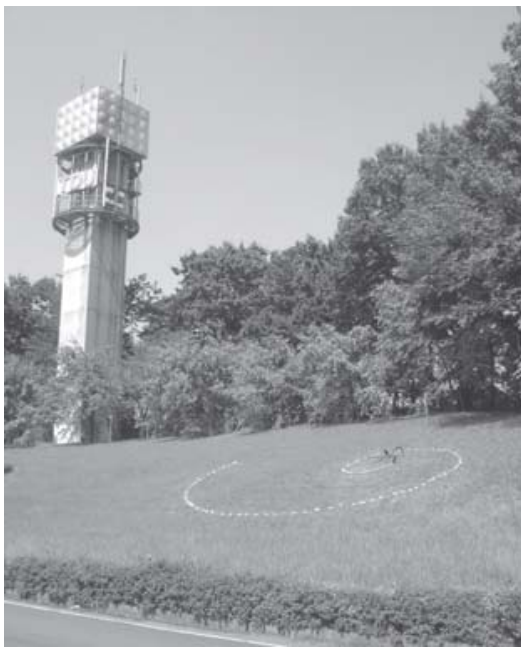

Gambar 7. M. Dwi Marianto, Track of Life Force (karya instalasi)

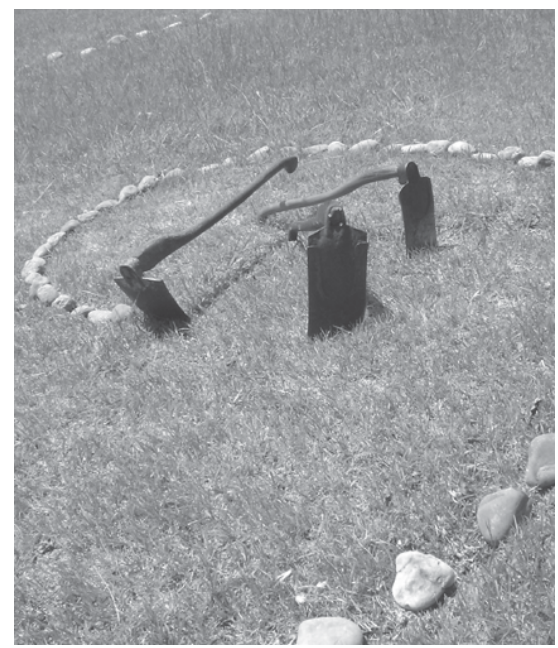

Gambar 8.

Deatail karya Track of Life Force

Satu-satunya karya instalasi yang disertai dengan suatu performance berupa tarian adalah karya Kaoru Ono yang adalah seorang penari pula. Ono membuat instalasi dari sejumlah mangkuk keramik yang dipasang pada penyangga logam, dan tidak jauh dari sana ia pasang tergantung satu instalasi yang dibuat dari potongan-potongan film negatif. Ia menari secara bebas di dekat karyanya, berpakaian putih panjang, bergerak-gerak bebas, melompat, meloncat mengikuti musik ilustrasi yang mengiringi. Ono juga menari dalam acara pembukaan, namun dalam acara ini ia berkostum dan menarikan tari India.

Helga Cmelka seniman dari Austria menampilkan suatu instalasi yang dibuat pada dua batang pohon, diberinya judul Dream Drops. Ia membuat instalasi berupa bongkahan-bongkahan yang dibungkus dengan suatu jaring yang dianyam dari tali. Pohon disini dibayangkan sedang menyangga tetesan-tetesan mimpi yang berubah menjadi gumpalangumpalan macam buah-buah yang menggerombol.

Karya-karya yang tergelar sangat jelas menyiratkan kebebasan para seniman dalam menginterpretasi thema yang digulirkan organiser guna memancing ide-ide kreatif dari para peserta. Media dan material yang dipakai bermacam-macam. Setiap orang tampil dengan dunia imaginasi masing-masing. Tempat yang dipilih juga sangat tergantung 
dengan sifat karya yang ditampilkan. Hutan, empang, sungai, jembatan, pepohonan, pematang jalan dalam semak dimanfaatkan. Itulah salah satu kekuatan TDU, punya kampus yang dikitari hutan. Tentang pepohonan yang rimbun dan hidup leluasa di seputar kampus, secara pribadi saya jadi bertanya-tanya: "Bukankah dulu di Indonesia tempat berbagai jenis tanaman tropik hidup dengan bebas, memberi manfaat yang besar kepada masyarakat sekitar?” Tentang kampus yang masih dikelilingi pepohonan, hanya kampus Universitas Indonesia di Depok, Jakarta lah yang masih bisa dibanggakan. Mereka punya sejumlah empang besar dan memelihara berbagai jenis pohon yang sudah mulai langka di daerah asalnya. Banyak suasana fisik kampus seni di Indonesia justru tidak estetis sama sekali bila ditengok dari kacamata ekosisistem, lantaran gersang, tak cukup diteduhi pepohonan yang berfungsi sebagai penahan, penarik air, dan pemberi oksigen murni secara cuma-cuma.

\section{Fenomena Menarik di Luar Forum IOE 2008}

Para seniman peserta diberi akomodasi di gedung National Women Education Centre, sebuah bangunan mirip hotel dimana berbagai pelatihan dan workshop untuk kaum wanita diselenggarakan. Boleh dibilang ini sebagai sebuah wisma milik pemerintah yang dikelola mirip hotel, secara disiplin dan profesional. Berbagai jenis pohon besar yang telah berusia puluhan tahun menghijaukan dan mengasrikan halamannya. Fasilitas toiletnya sangat istimewa, sebagai ilustrasi pada urinal di kamar mandi dilengkapi sistem penyiraman dari bawah dan dari belakang, dengan air yang tingkat kehangatannya bisa diatur. Sehingga orang yang buang air tinggal mengatur kedua cara penyiraman ini, serta posisi duduk untuk pembersihannya. Urinal dalam wisma itu tak kalah bersaing dibanding urinal hotel berbintang empat. Di sekitar hotel adalah daerah pemukiman yang dilengkapi dengan lapangan dan taman untuk olahraga dan rekreasi. Kalau pagi saya berjalan melihat-lihat suasana lingkungan di sekitar NWEC, mengamati sign system yang ada di seputar lokasi itu, dan landscape yang ada. Satu hal yang selalu menangkap perhatian saya adalah budaya merawat dan membiarkan potensi-potensi alam di sana. Beberapa selokan, aliran air dan situ di sekeliling benarbenar bebas dari sampah industri. Di tempat-tempat tertentu minimal ada dua kontainer sampah, untuk sampah organik dan sampah non- 
organik. Bahkan di TDU ada tiga macam kontainer untuk: botol plastik, benda-benda yang dapat terbakar, dan sampah organik. Burung gagak beterbangan di bebeberapa pohon besar dengan bebasnya. Kenyataan ini sangat kontras dengan apa yang terjadi di banyak daerah di Indonesia dimana orang bersenjata masih bebas dan bangga berkeliaran menembaki satwa yang hidup di alam terbuka. Selama berada di TDU saya memanfaatkan waktu luang dengan membuat sketsa atau drawing atas beberapa kenalan dalam forum IOE 2008, apakah itu seniman, mahasiswa volunteer, dan dosen. Salah seorang yang pernah saya skets itu adalah Profesor Ichino Manabu, bekas dekan di Departemen Informatika dan Seni. Melihat karakter sketsa saya, ia lalu menunjukkan kepada saya sebuah buku kaligrafi yang berupa kumpulan karya dari Koshun Masunaga yang tinggal di Tokyo, yang merupakan salah seorang kaligrafer kenamaan di Tokyo. Saya begitu terkesan dengan karyakaryanya yang dibuat dengan coretan-coretan garis yang spontan, kuat, tanpa pengulangan. Garis-garis karya Koshun sangat berkarakter, dalam garisnya ada esensi bentuk yang dinamis. Lalu atas prakarsa Profesor Ichino saya dipertemukan dengan Koshun Masunaga di Ueno. Pada 15 September 2008 kami berjumpa di sebuah rumah makan di dalam kawasan Ueno Station. Di sana ia menyerahkan sebuah buku berjudul Sou Boku (Calligraphic Colours) yang merupakan kumpulan dari karyakaryanya yang diseleksi. Koshun menerangkan bahwa manakala berkarya ia membayangkan dirinya sebagai seorang samurai yang memainkan katana, menebas dan menggerakkan senjatanya secara tegas penuh akurasi. Menggores dan menggaris pun demikian, semua dilakukan dengan satu tarikan pasti, disertai penjiwaan nan dalam. Apabila mau melukiskan seekor burung bangau, ia melakukan pengamatan yang mendalam atas burung bangau sampai ia dapat menangkap karakter dan esensinya, lalu dihadirkan via bahasa grafis. Yang menarik, setelah ia memberikan bukunya yang sudah dibubuhi tanda-tangan, ia menyodorkan sebuah buku drawing agar dibuatkan drawing atasnya oleh saya. Dengan bangga saya terima kehormatan itu, lalu saya buat drawing dengan Koshun Masunaga sebagai model.

Berkaitan dengan karya Koshun Masunaga yang merupakan pengembangan dari seni kaligrafi berbasis karakter Kanji, di Jepang karakter Kanji begitu menjiwai bahasa grafis yang menjadi tulang punggung sign system, logo, dan ungkapan kaligrafis yang mewarnai 


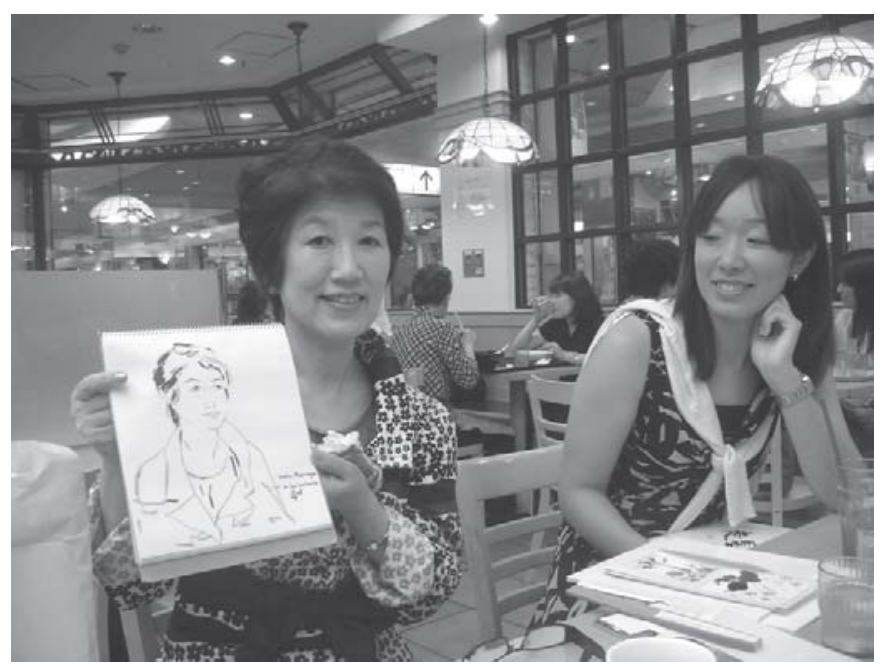

Gambar 9. Koshun Masunaga menunjukkan sketsa

tampilan kota, khususnya daerah bisnis, di Jepang. Building signs dengan karakter Kanji membentuk perwajahan grafis perkotaan. Sub budaya berkaligrafi ini memberi penghidupan bagi para seniman tradisi. Hanjyo Katsuki, seniman yang karya instalasinya disoroti diatas, adalah salah satu seniman kontemporer dengan karya-karya instalasi yang telah dipamerkan di sejumlah negara, ia salah seorang kaligrafer yang memperoleh penghasilan dari menerima order membuat kaligrafi.

Di Ueno saya menginap selama 3 malam di sebuah hotel kecil di seberang jalan raya dari Ueno Station, kira-kira 10 menit jalan santai dari stasiun ke hotel, kamar yang saya sewa kira-kira berukuran 4 meter x 2,5 meter, berkamarmandi dan toilet di dalamnya. Ongkos sewa kamar itu 5000 Yen per hari, dan harus dibayar sekaligus di muka. Tidak ada sarapan, hanya air panas dalam termos dan teh hijau. Kamar dilengkapi dengan satu unit televisi, namun praktis tidak dapat saya nikmati sepenuhnya, karena tidak ada stasiun kabel, jadi yang dapat saya tonton hanya channel-channel lokal yang semua disiarkan dalam bahasa Jepang. Suguhan yang pasti adalah acara pertandingan Sumo. Untuk mencari makanan saya harus berjalan ke daerah perbelanjaan seberang jalan dari Ueno Station tempat orang berjualan berbagai barang, makanan, minuman, buah-buahan, dan menyediakan sarana, permainan, dan berbagai jasa. 
Saya sengaja memanfaatkan jalan-jalan di daerah pertokoan, bisnis, dan taman kota untuk mengamati sign system dan ungkapanungkapan grafis yang mewarnai daerah itu. Yang saya utamakan adalah tanda-tanda, bahasa grafis, dan tanda berbasis kaligrafi untuk rumahrumah makan, toko-toko makanan dan minuman. Sangat menarik. Tandatanda atau ungkapan-ungkapam grafis yang ada sangat diwarnai oleh kaligrafi Kanji. Rasa spontanitas dan ekspresivitas sangat dominan dalam bahasa-bahasa grafis yang berbasis kaligrafi Kanji. Tapi terdapat banyak pula karakter-karakter Kanji yang distilisasi, atau disederhanakan sehingga lebih simpel dengan katajaman garis yang tegas guna memunculkan esensinya saja. Kaligrafi Jepang benar-benar menjadi tuan rumah di dalam bahasa grafis lingkungan dan dalam bahasa komunikasi produk-produk keseharian. Suatu tradisi yang tak terputus. Ini berbeda dari realita aksara lokal di Yogyakarta, yang kehilangan dasar pijakan budaya lokal di masyarakatnya sendiri. Aksara Jawa di Yogyakarta jadi bahasa grafis yang berstatus pinggiran, kurang-lebih sama nasibnya dengan aksara-aksara lokal atau ethnis di sejumlah daerah di Indonesia, tenggelam di bawah hegemoni aksara-aksara pendatang baru yang mendominasi - Latin dan Arabik.

Di Ueno saya dijadwalkan mengunjungi studio kriya logam dan studio keramik yang sangat penuh terfasilitasi dengan berbagai peralatan, berkisar dari piranti-piranti yang klasik atau tradisional, dan yang telah dioperasikan dengan mekanika modern. Yang saya kunjungi adalah Tokyo National University of Fine Arts and Music, yang berada di wilayah hijau. Saya diterima oleh seorang sensei metal casting - gurunya Seiko Kajiura - diantar berkeliling ke bagian-bagian dalam bengkel Kriya Logam melihat mesin-mesin, piranti-piranti kerja, bahan, serta material yang telah berevolusi selama berabad-abad. Pekerjaan metalcasting adalah aktivitas budaya yang produk-produknya dibutuhkan oleh masyarakat Jepang baik untuk kehidupan tradisinya maupun kehidupan yang modern, sebagai contoh: kuil-kuil dan tata-upacara membutuhkan benda-benda kebutuhan religius; tanda-tanda bangunan untuk tinggal, bisnis, serta perkantoran membutuhkan produk-produk metal-casting; gairah bermain dengan karakter-karakter dari logam seperti benda-benda robotik; barang-barang sauvenir banyak yang dihasilkan melalui teknologi metal-casting yang dikerjakan dengan tinggkat kekriyaan yang tinggi. Karya-karya berukuran mini dan besar diproduksi disana, dari yang realistik sampai yang simbolis kaligrafis. Kecanggihan metode 
kerja dan dalam pengelolaan kesinambungan material dan media yang dipakai merupakan satu aliran berisi tradisi budaya yang tak terputus sejak berabad-abad lalu. Ketika berada dalam studio kriya logam yang sangat kondusif itu saya teringat dengan sepenggal tulisan Tom Kelley (2001) dalam bukunya The Art of Innovation yang berbunyi bahwa kebutuhan adalah ibu dari segala penemuan. Pelajaran yang dapat dipetik disini adalah kenyataan bahwa kesinambungan suatu lembaga pendidikan akan sangat tergantung pada hubungan sinergis antara lembaga dan masyarakat pengguna lulusan lembaga yang bersangkutan. Dalam konteks ini suatu lembaga pendidikan seni harus selalu kreatif meng-up-date dan mengaktualisasi kurikulum dan orientasi program studi untuk disinkronkan dengan apa yang berkembang di masyarakat, dan secara strategis dalam hal ini lembaga pendidikan seni/disain/kriya harus terus berinovasi, berproduksi, dan memosisikan produk-produknya ke depan dalam upaya trend-setting strategis yang berkelanjutan.

\section{HIKMAH EKOLOGIS, ESTETIS, DAN KULTUR}

Pengalaman berada dan mengamati kehidupan budaya selama 9 hari di Jepang itu bagi saya merupakah hikmah luar-biasa dalam berbagai respek. Salah satunya, apa yang tergelar disana memang benar-benar berbeda dibanding apa yang tergelar di Tanah Air. Masing-masing punya keunikan dan alasannya sendiri mengapa terjadi demikian. Namun yang jelas berada di suatu tempat yang berbeda sama sekali dari apa yang kita alami sehari-hari sangatlah diperlukan untuk menjaga kreativitas, paling tidak dalam memandang dunia dan realitas sehari-hari. Karena salah satu cara untuk membangkitkan kreativitas adalah dengan menggeser cara atau sudut pandang atas sesuatu. Singkat kata begitu banyak hal yang sama sekali berbeda, atau yang memang tidak ada di Indonesia. Namun untuk penulisan artikel ini saya hanya mengekstrakkan dari pengalaman-pengalaman yang saya pilih, yaitu yang saya kategorisasikan dalam: hikmah ekologis; hikmah estetis; dan hikmah kultural. Di Saitama saya begitu terkesan dengan sungai-sungai dan selokan-selokan yang nyaris bebas dari limbah plastik, airnya jernih dan mengalir. Di taman-taman publik selalu tersedia fountain dengan semburan air jernih yang dapat langsung diminum. Air, saluran air, selokan, parit, dan sungai dikelola secara baik sekali. Budaya mengelola air dan yang berkait dengan perkara air selayaknya digarisbawahi sebagai 
pelajaran penting mengenai kearifan dan kebijaksanaan ekologis untuk bisa ditiru di Indonesia. Sebab sekarang ini sudah begitu jelas bahwa masyarakat-masyarakat di Indonesia belum mampu melihat potensi air dan lingkungan alam secara baik dalam cakrawala kesinambungan ekosistem. Sungai dan saluran air masih dipandang sebagai tempat pembuangan berbagai macam sampah - baik yang keras, lunak, maupun yang cair. Estetika keindahan alam dari sungai-sungai dan selokanselokan air yang jernih dan bersih hilang dari pemandangan nyata seharihari. Yang terjadi justru sebaliknya, yaitu sungai dan got-got dengan air yang tercemar. Di Ueno pohon-pohon besar, taman, empang besar penuh lotus mewarnai dan menyejuki jantung kota. Menjadi daerah resapan yang baik untuk kesinambungan air tanah. Di Ueno Park yang berada tidak jauh dari Ueno Station begitu hijau, sejuk dan asri, jadi tempat rekreasi warga kota dan para pelancong. Bebek, ikan, dan burung menandai tempat yang asri, terpelihara. Pohon-pohon besar taman dijaga dan dirawat, sebagai contoh: pada permukaan tanah di seputar kaki pohon dipasangi instalasi baja yang bolong-bolong macam penutup goronggotong, dimaksudkan agar air hujan dapat terserap ke tanah melalui lubang-lubang itu. Tanahnya pun masih bisa bernafas. Bukankah ini sangat berbeda dari pohon-pohon besar di banyak tempat di kota-kota di Indonesia yang biasanya tidak diperhatikan, apalagi dirawat. Yang terjadi justru sebaliknya, tanah di seputar batang pohon secara kedap dilapisi aspal, atau diplester semen secara rapat sehingga penyerapan air untuk kesinambungan pohon itu hanya terjadi secara minimal. Tidak sedikit pembakaran sampah dilakukan tepat pada kaki pohon, sehingga secara cepat atau lambat membunuh pohon yang bersangkutan. Dalam hal ini estetika yang peduli dengan kesinambungan ekosistem tidak terjadi. Sistem pembuangan sampah, dalam mana sampah dibagi menjadi tiga - botol plastik, barang-barang mudah terbakar, dan sampah organik - sudah tersosialisasi dengan baik, dan telah menjadi kesadaran umum masyarakat disana. Kesadaran macam inilah yang di Indonesia masih jauh dari kesadaran umum. Hikmah estetis saya ambil dari pengamatan atas karya-karya di, dan penyelenggaraan IOE 2008 Hiki, dan dari fenoemana seni yang sengaja saya pilih untuk diamati dari apa yang saya temui sepanjang journey saya. Kebebasan berekspresi secara individualistik sangat menonjol dalam forum seni. Setiap orang tampil dengan keunikan masing-masing, dengan pendekatan teknis maupun konsepsual yang beragam, kisarannya terdiri dari presentasi yang 
sederhana dan banal, yang masih mengandalkan kerumitan teknis dalam eksekusinya, sampai yang sudah bersifat konsepsual dan dihadirkan secara spesifik sesuai medan atau situs yang dipilih. Pada saat yang sama cabang seni yang telah jadi klasik seperti kaligrafi Jepang punya tempatnya sendiri. Pertemuan saya dengan Koshun Masunaga kaligrafer yang mengembangkan genre lukis sendiri dengan warnawarni kaligrafis - menginformasikan kepada saya tentang kaitan antara kaligrafi dengan pembayangan masyarakat tentang seni memainkan katana oleh seorang Samurai. Goresan kaligrafi Jepang berasosiasi dengan sabetan katana yang tidak mengobral gerak-gerak kembangan, namun selalu dengan sabetan esensial yang langsung ke sasaran. Perjumpaan saya dengan Koshun Masunaga dan pemaparannya tentang kaligrafis Jepang yang dikembangkan dari kaligrafi Kanji yang berasal dari China, membuat fenomena grafis seperti building signs dan corporate signs yang disusun dari karakter-karakter Kanji, Hiragana, dan Katakana menjadi tambah menarik, sebab dengan sendirinya produkproduk grafis itu punya karakter dan kekhasan. Yang terakhir namun tidak lebih kecil maknanya adalah hikmah kultural. Budaya menghargai kebebasan berekspresi dan menampilkan karya seni dengan pendekatan pribadi nampaknya sudah menjadi kecenderungan umum. Penghargaan atas waktu, dan budaya tepat waktu telah terbudaya secara baik, ini terlihat dalam beberapa pertemuan yang dilakukan. Hal ini sejalan dengan sistem transportasi umum di Jepang, seperti perkeretaapian yang telah dikelola secara tertib, bersih dan tepat waktu. Sampah juga telah dikelola secara baik, dan terdukung dengan kesadaran masyarakat akan kebersihan serta keasrian lingkungan. Dalam berbagai kesempatan yang saya ikuti dapat saya katakan bahwa tidak nampak praktek-praktek berpanjang-panjang-lebar dengan pernyataan-pernyataan lisan. Pidato dan sambutan-sambutan dari pejabat satu yang disambung dengan pejabat yang lain tidak nampak dalam acara yang saya saksikan dalam IOE 2008. Walau tak ternyatakan secara eksplisit, masyarakat di Jepang lebih memilih untuk menyatakan sesuatu dengan karya dan tindakan nyata, daripada dengan kata-kata. Budaya mengemas sesuatu secara indah dan efisien dapat dilihat dalam berbagai produk yang beredar di pasaran. Sebagai contoh, di toko kelontong di Jepang biasanya menjual berbagai macam makanan untuk langsung dikonsumsi, misalnya makanan sarapan yang terbuat dari nasi dan ikan tuna yang dikemas secara baik dan asri dalam kemasan kertas yang tahan air. Bungkusan 
makanan itu didisain sedemikian rupa, dilengkapi dengan instruksi grafis, dengan urutan-urutan yang jelas, guna membantu konsumen untuk membuka kemasan produk makanan yang dimaksud dengan mudah dan praktis. Banyak sekali pelajaran tentang budaya yang tergelar dalam perjalanan saya di Jepang. Tentu saja ada yang baik dan ada yang buruk, ada yang sangat tepat bila diterapkan di Indonesia, namun ada pula yang barangkali tidak pas dengan kondisi dan situasi alam dan budaya di Nusantara. Namun yang pasti adalah kenyataan bahwa keberhasilan, ketertiban, efisiensi, keasrian lingkungan, kebebasan berekspresi dan bereksplorasi, sikap menghargai ruang dan waktu yang dapat disaksikan dalam suasana keseharian di Jepang tidak datang secara tiba-tiba sebagai suatu keniscayaan, melainkan telah dilakukan dan disosialisasikan melalui waktu yang panjang, dengan kerja-keras dan kedisiplinan, dan dengan semangat dan dinamika untuk terus berjalan ke depan menggapai yang lebih baik dan indah.

\section{PENUTUP}

Sesekali kita memang perlu mengikuti perhelatan seni di luar wilayah kerja kita yang bersifat rutin, apakah itu di dalam atau di luar negeri, di luar atau di dalam kota, di dalam atau di luar disiplin kita, agar kita terbebaskan dari kotak rutinitas kita, dan bahkan kalau perlu agar kita bisa sepenuhnya sadar akan habitus kita untuk diatasi atau dilampaui. IOE 2008 Hiki sama dengan perhelatan seni lain di manapun berada, mengandung potensi-potensi yang kait-mengait dengan kesekarangan. Potensi-potensi itu hanya akan mengemuka dan bermakna bila kita mau membuka hati dan membiarkan diri kita dipengaruhi oleh apa-apa yang tergelar secara nyata maupun yang tersirat dalam ungkapanungkapan metaforik. Inilah salah satu fungsi berkesenian dengan keterbukaan, agar kita bisa melihat dan menyadari akan apa yang hidup dalam dan di sekitar kita. 
MUDRA VOLUME 24 NO.1 JANUARI 2009

\section{DAFTAR PUSTAKA}

Arthur Asa Berger. 1984, Signs in Contemporary Culture, London: Longman.

Matin Heidegger. 1971, On the Way to Language, New York: Harper \& Row.

Fransisco Budi Hardiman. 2003, Heidegger dan Mistik Keseharian, Jakarta: KPG.

Tom Kelley. 2001, The Art of Innovation, New York: Barnes \& Nobles 